\title{
Glutathione S-Transferase Mu 3
}

National Cancer Institute

\section{Source}

National Cancer Institute. Glutathione S-Transferase Mu 3. NCI Thesaurus. Code C112074.

Glutathione S-transferase Mu 3 (225 aa, $27 \mathrm{kDa}$ ) is encoded by the human GST M3 gene. This protein is involved in cellular detoxification of glutathione, nitrogenous compounds and other xenobiotics. 